\title{
Beyond the Golden Era: Asia Pacific Cooperation after the Global Financial Crisis
}

\author{
Peter A. Petri \\ Brandeis University and East-West Center
}

15 November 2010

\begin{abstract}
The half century leading up to the crisis of 2008-2009 was the best such period in world economic history, especially in the Asia Pacific. Peace and relative economic stability permitted unprecedented liberalization, economic integration, and advances in productivity and growth. But the institutions and strategies of this system are hitting roadblocks. Economic power has become more diffuse and the challenges for cooperation more complex. The world trading system may be entering a period of "contested stability"- continuity with limited prospects for forward progress. In this system cooperation will involve managing interdependence rather than negotiating new agreements. A new, layered approach to cooperation is likely to emerge, with stronger bilateral and regional mechanisms complementing weaker global processes, such as the G-20. World growth need not suffer if new, distributed drivers of productivity emerge to replace deepening economic integration as the engine of progress.
\end{abstract}

JEL Classifications: F01, F02, F13, F15, F53.

Key phrases: Asian economic growth, international cooperation, globalization, interdependence, WTO, trade policy.

Based on a draft presented at the PAFTAD 33 Conference, 6-8 October 2009, Taipei, Taiwan. 


\section{TABLE OF CONTENTS}

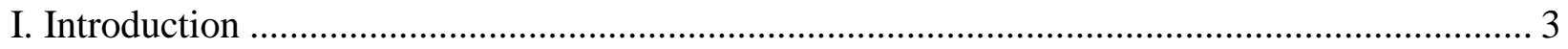

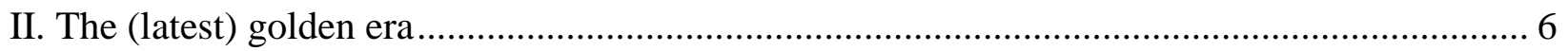

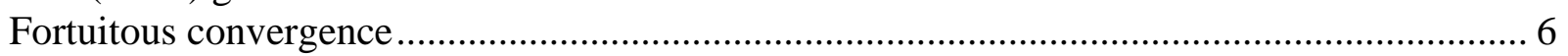

Figure 1. The golden age in historical perspective ..................................................... 6

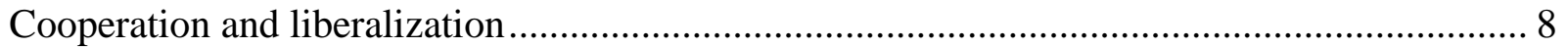

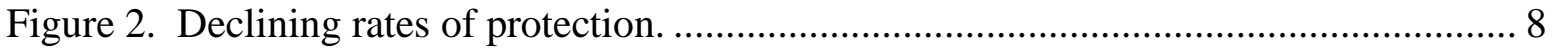

Figure 3. Relationship between rounds and countries. .............................................. 9

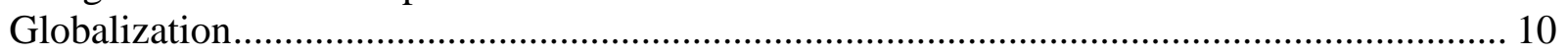

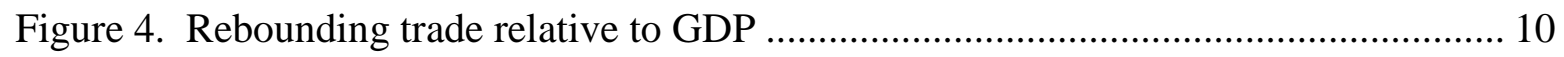

Figure 5. Explosion of global capital flows ............................................................. 10

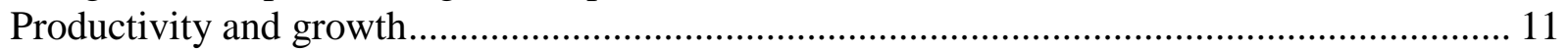

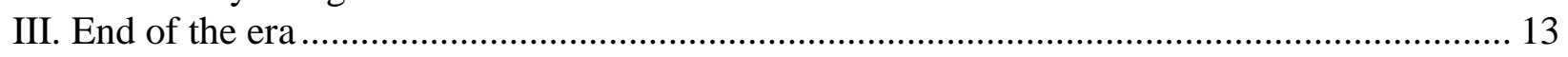

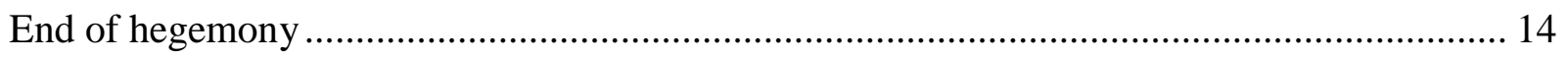

Figure 6. Shifting economic power: shares of output. ............................................ 15

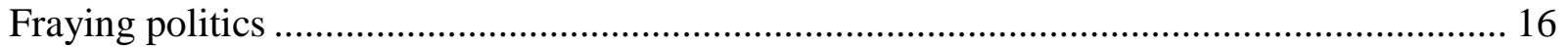

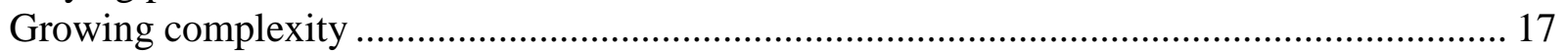

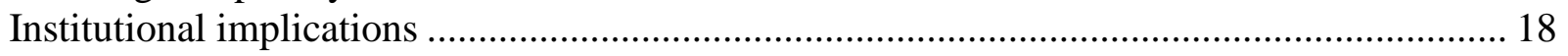

Figure 7. Share of regional trade covered by FTAs.................................................. 18

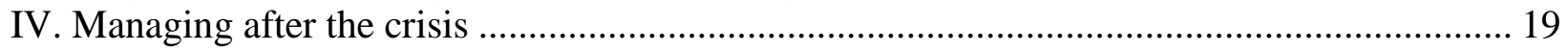

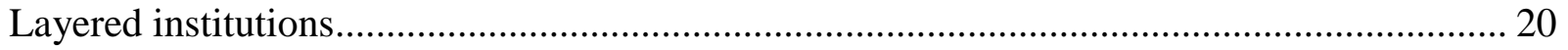

Figure 8. The governance trilemma ..................................................................... 21

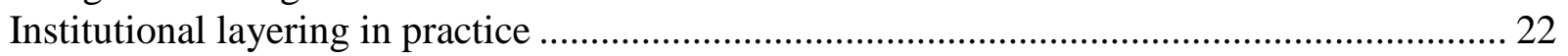

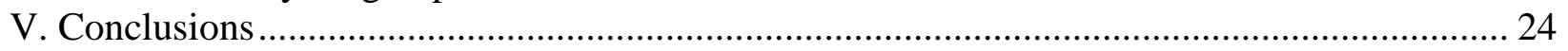

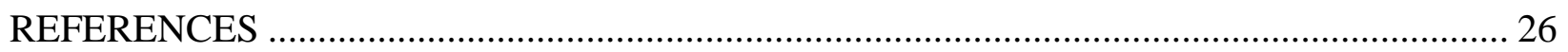

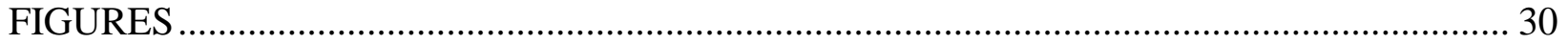




\section{Beyond the Golden Era: \\ Asia Pacific Cooperation after the Global Financial Crisis}

Peter A. Petri ${ }^{1}$

\section{Introduction}

Forty-five years after Professor Kiyoshi Kojima's plan for a Pacific Free Trade Area gave birth to PAFTAD (Patrick 1996, Terada 1999) reality is approaching his vision. The region has become highly integrated and most of its economies are embarked on robust, market-based development. Living standards have risen beyond expectations, and even the PAFTAD optimists of 1968 would be surprised to see how effectively Asia is now leading the recovery from a global crisis that originated in the United States. In 2006, Asia Pacific Economic Cooperation (APEC) leaders called for a Free Trade Area of the Asia Pacific, and three different regional negotiating tracks appear to provide pathways toward it.

There is also strong evidence that deepening international interdependence, especially in the Asia Pacific, contributed to the unprecedented economic progress of the past half century. Yet the institutional strategies that led to these accomplishments are hitting roadblocks. Even before the global financial crisis of 2008-09, international trade negotiations had reached an impasse. The crisis uncovered gaps in cooperation on macroeconomic and financial issues. Another new global process, to mitigate climate change, has run aground. Economic and political tensions are rising, including between the United States, China and Japan, the region's three largest economies. Established institutions of cooperation appear unequipped to manage these challenges - indeed, the Bretton Woods institutions have been largely bystanders in recent global policy debates.

These worrying developments raise deeper questions. What explains the fragility of the global framework after such remarkable results, despite the continued vitality of international trade and

${ }^{1}$ Carl J. Shapiro Professor of International Finance, Brandeis International Business School, and Senior Fellow, East-West Center, Honolulu Hawaii. Email: ppetri@brandeis.edu. The author gratefully acknowledges helpful comments by Professor Wendy Dobson and other participants at the PAFTAD 33 conference in Taipei, October 2009. 
investment? Is the solution simply institutional innovation — revisions of voting rights in the Bretton Woods institutions and the new G-20 leaders' process? Or are there fundamental reasons to expect different or less effective forms of international cooperation in the future? And if so, will economic performance suffer?

This paper concludes that the difficulty of mounting new cooperative efforts is not likely to be temporary —indeed, the "golden era" of growth driven by ambitious new liberalization measures may have come to an end. The argument is based on three interrelated trends. First, the leadership role of the United States in organizing global cooperation is fading, due to the diffusion of economic of power. Second, domestic political support for international cooperation is declining in many countries. Third, despite the stiffening headwinds, international initiatives have taken on more complex and politically difficult issues as attention has shifted from border barriers to behind-the-border regulations.

The interplay of these trends has led to skepticism by the public and many policy makers about the possibilities for, and benefits of, further global agreements. Global cooperation has slowed. At the same time, negotiations have shifted to other levels, where the trends are less adverse, but the results of cooperation are also more limited. At turning points it's especially difficult to predict what will come next, but several alternative directions can be envisioned:

- Leadership for global cooperation will reemerge, perhaps in new form (based on the G-20) under the joint leadership of a few dynamic advanced and emerging economies.

- International decisions will move to new, more limited forums - involving pairs or small groups of countries, regions and other "clubs"- but these will remain somewhat responsive to directions established by the G-20 and/or international institutions.

- Central coordination will wither as countries adopt policies that can be implemented independently or in small groups. (For example, by pursuing regional trade agreements and self insurance against macroeconomic shocks.) 
Under the second and third scenarios — which we consider more likely — cooperation will be more complicated than it was during much of the post-war period. ${ }^{2}$ More countries and more varied institutions (bilateral, regional, global) will be involved in "cooperation." The system will resemble governance in a heterogeneous country that has many voices, provinces and layers of government. Decision-making authority in such a system is diffuse and policy directions switch from time to time as different groups achieve dominance. In this context, global institutions are likely to follow rather than lead policy, and policy is unlikely to evolve rapidly. This outcome might be best described as "contested stability"-little forward progress, but also reasonable continuity of the existing framework. The strategies needed to manage such a system will be different from those that were useful in managing cooperation in the past.

Given the important role of economic integration in the past half century, one might conclude that a slowdown in liberalization will lead to much worse economic outcomes. But that does not follow. The issue hinges on distinguishing levels of integration from changes in integration. Growth could remain robust even if the process of economic integration slows, provided that the drivers of growth shift from integration to other national and regional development engines. With growth based on more diverse processes, it may be enough to sustain existing integration, and this could be accomplished with less cooperation than was required to build an integrated global system. As long as barriers can be kept from rising, countries can remain specialized in areas consistent with their comparative advantage - reaping most of the potential gains from trade-while relying on other sources of productivity to drive growth.

The paper addresses the prospects for cooperation primarily in trade and other "real" economic linkages. ${ }^{3}$ It begins by reviewing the achievements of the post-war era and the institutions that brought them about, with particular attention to liberalization and integration as drivers of globalization. It next considers signs of failure in the system, including the deceleration of

\footnotetext{
${ }^{2}$ This discussion is limited to cooperation among market economies, and abstracts from the complications posed by the parallel, though for the most part independent, systems that operated for market economies and socialist economies until the fall of the Soviet Union.

${ }^{3}$ The reasons for this narrow focus are to limit the length of the discussion and to make it more specific through consistent examples. The arguments may well carry through to other areas of cooperation since they are based on the club-theoretic determinants of international economic relations, but a more careful application would be needed to substantiate this expectation.
} 
cooperation and the fraying political economy of liberalization. It then examines the implications of these trends for future cooperation and for institutional changes that are likely to be required. These are large and speculative topics, and the paper is more concerned with formulating questions and approaches to analysis rather than reaching specific conclusions.

\section{The (latest) golden era}

The half century leading up to the global financial crisis of 2008-2009 was the best such period in history (see Figure 1). ${ }^{4}$ Between World War II and 2008 the world economy left behind the Great Depression and the state-led models that followed it, and became market-oriented, integrated and enormously successful. The achievements of this golden era built on, but easily surpassed, the achievements of 1870-1913, the previous golden age. The reason is that after World War II technological progress came together with (relative) peace and economic stability, and this permitted the creation of an unusual global economic order. This period saw sustained cooperation and liberalization, resulting in unprecedented economic integration, and this in turn brought remarkable advances in productivity and growth to much of the world.

\section{Fortuitous convergence}

The current golden era was the culmination of a process of acceleration that began in 1870-1913, when the world's growth rate doubled from the prior half century. Maddison attributed the acceleration to new technologies, specifically improvements in health, which lead to population growth, and in power generation and transportation, which led to productivity growth. But he also emphasized that these advances had large-scale effects because they affected growth widely due to globalization. Immigration, capital and trade flows helped to turn isolated technological discoveries into engines for world growth (see Figures 4 and 5 below).

Figure 1. The golden age in historical perspective

The acceleration before World War I was reversed as the world succumbed to two devastating wars and the Great Depression. Technology continued to advance - important new products and services were introduced and/or adopted, including electric power, automobiles, airplanes and

\footnotetext{
${ }^{4}$ Maddison (2001) provides a global overview, Maddison (2003) provides detail for the Asia Pacific.
} 
the telephone - but could not overcome the collapse of economic "software" as monetary, financial and trading systems reverted to conditions of earlier decades.

The end of World War II reignited the growth process. Over the next several decades growth rates remained high, reached a wider geographic base, and in many regions accelerated. Worldwide, growth doubled the previous record. Technology and productivity provided the foundations but other critical pieces fell into place. Peace, the rise of markets and international economic liberalization enabled the development of the software - a integrated, market-based global economy - that put the technology to work.

Post-World War II policy did not set out in a liberal direction but it ended up there. The architects of Bretton Woods wanted an to end the protectionist excesses of the inter-war era, to be sure, but they also tightly circumscribed international transactions with fixed exchange rates, capital controls, and barriers to trade, partly because they blamed the disaster of the 1930s in part on laissez faire policies. Scholars argued that macroeconomic stability required sacrifices in efficiency (Irwin 1996a, p. 202). An active state was also seen as essential for development due to coordination problems (Rosenstein-Rodan 1943, and Leibenstein 1957). This led to "big bang" strategies featuring planning, import substitution and even nationalization. Exchange controls continued for many years after the Bretton Woods; for example, the yen become convertible even for current account purposes only in 1972, and the British pound only in 1979.

As the global economy prospered, the "commanding heights" role of government withered. In some areas governments were overwhelmed by markets (for example, in maintaining a fixed exchange rate between the dollar and gold). The market became more adapt at circumventing regulations, say, through off-shore investments or by obtaining freedoms in special economic zones. Scholars shifted their attention from market failure to government failure and rent seeking (Krueger 1974) and liberalization came to dominate the recommendations of professional economics, as summarized in the "Washington Consensus" (Williamson 1989). ${ }^{5}$ In

\footnotetext{
${ }^{5}$ Ironically the term has become associated with policy failures that contributed to the Asian financial crisis of 1997-98. In fact there was little consensus on capital account liberalization then (it was not included among Williamson's principles) and development policy in many countries otherwise remains consistent with "Washington Consensus" prescriptions.
} 
this view, the role of government was to guarantee stability, provide infrastructure, and facilitate investment and competition. While Asian experience provided successful examples of government intervention, these incorporated significant reliance on markets, and were often interpreted as confirming a market-friendly approach to policy (World Bank 1991, 1994).

\section{Cooperation and liberalization}

Effective global institutions were a key pillar of progress in the golden era. Although the Bretton Woods plan for an International Trade Organization initially failed, ${ }^{6}$ the General Agreement on Tariffs and Trade (GATT) process delivered eight unprecedented international agreements, dramatically lowering tariffs and other barriers to trade (Figure 2). The Uruguay Round was the most recent and ambitious result of this system. This remarkable agreement — and it looks increasingly so in retrospect-lowered tariffs, brought agriculture and services into the international framework, added a cluster of trade-related policies, made the coverage of trade global and universal and, most importantly, established the World Trade Organization (WTO) to enforce global rules and promote additional negotiations. With hindsight, this result appears to have been the product of exceptional cohesion in the world economy, most likely associated with the collapse of the Soviet Union.

\section{Figure 2. Declining rates of protection.}

But as its achievements mounted, the trading system was also becoming less workable. The membership of GATT and eventually the WTO expanded, requiring new efforts to keep decision-making manageable. None proved sustainable. In 1975 a "Consultative Group of Eighteen" was established, but succumbed in 1987 to the criticism that it lacked transparency. A less formal approach involved gathering key delegations in a "Green room" (a room adjoining the Director-General's offices), but this too was criticized by excluded countries. The Quadtrade ministers of Canada, the European Union, Japan and the United States-came into existence in 1982 and played a central role in the Uruguay Round, but its disagreements were blamed for the debacle of the 1999 Seattle ministerial and the Quad has since faded. Various steering committees with representative members, akin to the boards of the World Bank and the

\footnotetext{
${ }^{6}$ The Havana Charter of 1948 was endorsed by 53 countries but could not surmount concerns in the US Congress that the Charter would permit other countries to impose trade restrictions and limit the ability of the United States to do so (Cohn 2002).
} 
IMF, have been proposed and blocked by both small countries which might be excluded and large ones that don't want their role diluted. ${ }^{7}$

The Uruguay Round overcame these problems — arguably due to lucky circumstances — but made future negotiations far more difficult. One key achievement of the Round was the principle of a "single undertaking," requiring participants to accept all provisions of WTO agreements (subject only to varying transition periods and minor exceptions for developing countries). This made the system truly global — and incredibly hard to administer. The single undertaking concept transformed the world trading system from one that addressed selected trade practices among a few advanced economies to one that targeted many trade-related domestic policies across roughly 150 members (Barton et al. 2006). This put the WTO squarely into the middle of national political debates. And since countries could not opt out of unacceptable provisions, they had to resist any agreement that had rules they didn't like. With near universal expansion of GATT/WTO membership, these developments vastly complicated the task of reaching new agreements (Figure 3).

Figure 3. Relationship between rounds and countries.

So far, no viable mechanism has emerged for resolving the divisions within the WTO, especially between developed and developing countries. The requirement for consensus on all issues dims the prospects for a meaningful agreement. Even with vigorous leadership — say, by G-20 heads of state-it would be difficult to strike a meaningful bargain across the WTO's enormous portfolio (Barton et al. 2006). Many observers sympathetic to the WTO process now hope for a modest Doha deal simply to clear the deck for other, more manageable approaches.

To be sure, the stalemate on forward progress is at most half the story. By the time these trends materialized, the WTO had evolved into a reasonably effective mechanism for overseeing world trade. Its dispute resolution mechanism (DRM), best understood as a mechanism for adjudicating self-enforcing rules, manages extensive conventions that provide discipline. The DRM is largely accepted by members and its utilization is rising. Even during the global recession, WTO disciplines and technical oversight—supported by G-20 resolutions against

\footnotetext{
${ }^{7}$ See Schott (2000).
} 
protectionism - helped to contain the pressures that arise in downturns. The WTO adds value to the global trading system as it is, whether or not it produces new agreements.

\section{Globalization}

Cooperation and liberalization led to a dramatic deepening of global economic integration, or what we now call globalization. This was not the first era of globalization (Bordo 1998, Irwin 1996b), but international linkages set records in most dimensions (the exception is labor flows, which were higher under the immigration regimes of the pre-World War I era). The ratio of trade to GDP is one measure of these trends (Figure 4). As Feenstra (1998) noted, this indicator understates volume increases because the prices of tradeables have declined relative to nontradeables. There is also evidence that economic connections have become more diverse; trade has shifted from primary materials to varied manufactures and increasingly services (Findlay and O’Rourke 2001). Capital flows also picked up following the collapse of Bretton Woods (Dobson et al. 2001) and recently accelerated again (Figure 5); between 1990 and 2007 the share of crossborder investments in world GDP roughly quadrupled, growing at an average annual rate of $15 \%$.

Figure 4. Rebounding trade relative to GDP

Figure 5. Explosion of global capital flows

Whether the GATT/WTO was in fact a "cause" of these trends has been questioned by Rose (2007), who showed that participation in GATT/WTO did not appear to increase the trade volumes of member countries relative to non-members. Separating the effectiveness of the framework from other factors that affected trade is inherently difficult, but in any case subsequent analyses have reconfirmed the positive effect of GATT/WTO membership on trade. The treatment of non-GATT/WTO economic relations among countries (such as colonial ties, free trade areas, and currency unions) is especially important in the statistical analysis. For example, studies that redefine GATT membership to include colonies of members (to reflect the fact that colonies received GATT privileges corresponding to members) find membership to have a positive effect (Tomz et al. 2007a, Tomz 2007b). So do still other studies that control for 
other types of ties (Gowa 2009). The latter concludes, for example, that signatories of global rules trade 42 percent more with each other than non-signatories. ${ }^{8}$

To be sure, the effects of liberalization have not been uniform across countries. Interdependence has deepened especially fast among economies with preconditions that enabled them to exploit global opportunities (World Bank 1990), and among neighboring or otherwise closely related countries (Coe et al. 2002), especially in Asia (Capannelli et al. 2010). There is no reason why falling communications and transport costs should lead to geographically concentrated linkages, but they nevertheless appear to do so. One hypothesis explaining this finding is that technology and economies of scale have become more ubiquitous, so that firms no longer have to reach over long distances to obtain specialized products. Another hypothesis focuses on the nature of falling transport costs; these contribute to the physical decentralization of production, but at the same time make coordination costs more important. Coordination costs may be lower in regional setting because they depend on factors such as cultural similarity and historical ties, ease of personal travel, and common time zones.

\section{Productivity and growth}

Integration into the global economy and associated gains from trade and productivity appear to have made a direct contribution to the acceleration of growth. The gains in income and the quality of life have been nothing short of remarkable. Between 1960 and 2007, the world's ${ }^{9}$ :

- real GDP increased more than five-fold;

- per capita incomes nearly tripled;

- real trade increased fourteen times (three times as fast as output);

- life expectancy increased by one-third; and

- population more than doubled.

Some of these gains are no doubt due to the development and diffusion of technology

\footnotetext{
${ }^{8}$ This is a large increase for an institutional contribution, which is of course difficult to measure. Somewhat puzzlingly, Gowa herself minimizes the importance of the contribution, noting that trade increased manifold during this period.

${ }^{9}$ Calculations are based on World Bank, World Development Indicators, extracted September 25, 2009.
} 
independently of globalization, but there also appears to be a strong, direct relationship between integration and economic success.

Although the positive effect of outward orientation on growth came to be widely accepted by policy makers and economists, its rigorous testing is relatively recent. Sachs and Warner (1995) laid the groundwork for what has become a very substantial series of studies to explore the connection between economic integration and economic growth. Nearly all have found a positive association. To be sure, the existence of causal relationship has been challenged on the grounds that underlying economic institutions, rather than liberalization, might have been responsible for the results (for example, Easterly 2005). That argument doesn't detract from the value of integration, but it does qualify the conditions under which it is likely to be effective. Yet some recent, careful studies also continue to find an independent causal link (Estevadeordal and Taylor 2008).

As interdependence has deepened, the production process has been transformed. As is widely documented, production now involves fragmented supply chains with narrow processes located in different countries to exploit factor cost savings and/or economies of agglomeration. This has generated major new opportunities for productivity gains in both "outsourcing" firms that transfer processes abroad and foreign firms that take on these activities. At the same time, production chains have made the politics of trade policy more complicated. Firms have varied, overlapping interests in different countries and exchange rates.

Whether the effect of integration on growth was due to liberalization alone or to liberalization under favorable institutions, the welfare gains have been unprecedented. Nothing like the achievements of this half century had been seen before - not in the degree of integration, not in the geographical expansion of the "convergence club" to emerging economies including especially in Asia, and not in terms of overall economic progress. 


\section{End of the era}

The unique drivers of growth in the golden era - a qualitative jump in economic integration and in cooperative institutions - appear to be slowing. This is due to both geopolitical and structural causes. The geopolitical causes involve two trends: the end of global political blocs and the diffusion of economic power. In a multi-polar world, countries and interest groups make decisions based on economic self-interest rather than power politics or global outcomes, and it becomes increasingly difficult to form coalitions and sustain collective action.

The structural causes involve falling benefit/cost ratios along the path of liberalization and the growing intricacy of barriers in complex economies. Sustained liberalization has reduced the most costly barriers and has also left behind obstacles that cannot be addressed without high political cost. These are not likely to be addressed in global agreements, although they may be finessed (or left unaddressed) in bilateral or regional agreements. For example, deeper integration in services could still offer large economic benefits worldwide, but the policies required are so complex and/or contentious that they are unlikely to be negotiated on a global level.

While both geopolitical and structural factors suggest diminished prospects for new liberalization - a negative second derivative in liberalization - they do not necessarily imply a reversal in the level of liberalization. The fact that further progress is difficult does not argue for returning to earlier interventions. But even if generally market-friendly economic policies remain in place, growth is no longer likely to be driven by further jumps in liberalization, as it was in the past.

The deceleration of liberalization also does not have to imply slower growth. The outlook for several key determinants of world growth - savings and investment, technological progress, the spread of ideas across the world - is bright, reflecting the rising scale of innovative activity (endogenous growth) and improved access to knowledge. There are especially strong reasons to be optimistic in Asia. These drivers of growth could raise productivity in parallel across countries, without depending on increased exchanges of products. In turn, such a shift in the 
sources of world growth - from productivity based on deeper integration to productivity based on parallel productivity advances - would have major implications for the structure of economic cooperation and the institutions required to support it.

\section{End of hegemony}

The most obvious reason for slowing liberalization is the erosion of the hegemonic role of the United States in the world economy. In the early post-World War II period, the United States produced nearly $1 / 2$ of world output (twice as much as Europe and four times as much as Asia) and its interests were very closely allied with those of the world economy. The United States welcomed liberalization and was in a position to coerce others to its viewpoint. And it had a large enough stake in the world economy to provide public goods-including trade concessions - that benefited other countries.

The United States grew reasonably fast in the past half century, but Europe, Japan and several smaller economies have caught up in terms of per capita income. Large, low-income economies like China and other "BRIICs" have also become very important in absolute scale. Meanwhile, America's disproportionate military power - a critical source of influence in the politics of the Soviet era-became less important in forming economic coalitions. These developments have been underway for some time (Keohane 1984) but gained momentum with the collapse of the Soviet bloc and the rise of Asia.

The global financial crisis further diminished the prospects of the United States and boosted Asia's. Asia survived the crisis with less damage, less debt and stronger fundamentals. ${ }^{10}$ Figure 6 provides a conservative measure of the shifts in global economic power by plotting the shares of GDP (at market prices) for the United States, Asia and Europe. In 2010, the shares of all three are roughly equal in the 20 percent range. As the shares continue to shift over the next 20 years, Asia will reverse its relative position compared to the United States and Europe in 1990 (Petri

\footnotetext{
${ }^{10}$ This paper is focused on the Asia Pacific, but growth poles have also emerged in Latin America, based on similar policy strategies. Latin American economic integration through MERCOSUR, a trade zone initially criticized for diverting more trade than it creates, has become more open by including the Andean Community countries and by gradually reducing extra-MERCOSUR barriers.
} 
2010). Meanwhile, each bloc is also multi-polar; Asia itself consists of four major components with potentially diverging policy perspectives: China, Japan, India and ASEAN.

\section{Figure 6. Shifting economic power: shares of output.}

As new regional growth poles emerge, economic institutions follow in their wake, fragmenting the global system. Europe's transformation into the European Union is the most prominent example - indeed, Professor Kojima's vision for Asia was based on the European experience. The diversity of Asia has prevented such formal institutions so far, but there has been progress (ADB 2008). A promising institutional track has emerged around ASEAN, reflecting in part integration within ASEAN through the ASEAN Free Trade Area and the 2007 blueprint for an ASEAN Economic Community. ASEAN's relations with "plus three" partners (China, Japan and Korea) have formed a basis for regional financial cooperation through the Chiang Mai Initiative and have led to proposals for a free trade area (East Asian Free Trade Area, or EAFTA). ASEAN has also become the hub of a wider trade initiative that would include Australia, New Zealand and India (Comprehensive Economic Partnership for East Asia, or CEPEA), and its East Asian Summit will now also include the United States and Russia.

The dispersion of world economic activity has also led to calls for revising the governance of the IMF, World Bank and other global institutions. More accurate representation of current economic conditions will make these institutions more legitimate, but not necessarily better at achieving global consensus. More diffuse voting power and accountability could instead lead to more deadlock. At the same time, much is expected of them: the IMF has been identified by the G-20 as its agent for the Mutual Assessment Process (MAP), but it has little leverage beyond its ability to lend to smaller economies. For example, when the IMF extended its overview to exchange rate policy prior to the crisis, China discontinued its Article IV consultations. The IMF failed to persuade major economies to control imbalances in 2006 and has had little effect on policy since the crisis. Sustained G-20 cooperation would be needed to make IMF surveillance effective - a tall order in the light of recent experience. 


\section{Fraying politics}

A second reason for slowing liberalization is that domestic politics is becoming less supportive of international initiatives in many countries. Rodrik (2003) has argued that special factors were involved in the positive politics of trade in the golden era. Liberalization normally benefits workers in countries with wages below the world averages, so it tends to be more popular in poor countries than in wealthy ones. Nevertheless, in the post-World War II era the United States emerged as a champion of global liberalization because it was strong enough to shape the liberalization agenda in ways that benefited its own producers. But these conditions, which made trade attractive to both "poor" Europe and the "rich" United States, have now evaporated.

The politics of trade has also become intertwined with rising income inequality. Most studies suggest that this phenomenon - and particularly the stagnation of wages for low- to mid-wage workers in advanced countries - is due more to technological change than to expanded international trade, as improvements in information technology have taken a toll on the value of low-skilled labor. In addition, improved communications have expanded markets within and across countries, and these larger global markets often have "winner take all" characteristics. Whatever the causes may be, inequality is routinely blamed on international competition and globalization, and is used as political ammunition by groups opposed to liberalization.

Meanwhile, governance across the world has become more pluralistic and sensitive to such concerns. New, vigorous democracies are now operating in Asia. Even in countries where democratic institutions are not new, as in Japan and the United States, the political process has become more contestable and less stable. Short-horizon politics works against liberalization because liberalization tends to impose adjustment costs in the short term and deliver benefits in the longer term. Regional economic integration has emerged as an alternative to global agreements in part because it gives countries more control over political costs.

The complexity of trade - explored further below — has also made business support less predictable. Exporting firms in advanced economies have often acquired foreign operations that compete with imports entering a foreign economy, or depend on a foreign host government's goodwill to be successful. They have become less vocal champions of trade. (To be sure, 
outsourcing has transformed some import competing firms into intermediate goods importersin effect making them champions rather than opponents of trade.) While business still generally supports freer trade, its most important goal now is not so much additional liberalization as maintaining good relations with governments to avoid adverse regulation.

\section{Growing complexity}

The third challenge facing new liberalization initiatives is the growing complexity of the global agenda. This partly reflects the growth and sophistication of the world economy. It also reflects the success of past negotiations, which typically expended the policy agenda. As interdependence has deepened it has become more intricate; world trade has risen three times as fast as output and real international transactions are fourteen times as great in 2008 as they were in 1960. A much larger share of activities, transactions and related policies are now "international."

Interdependence has also become more multi-dimensional. Direct investment and intellectual property flows (as measured by patents or royalty payments) have grown faster than trade. The fragmentation of production require complex logistics and complementary flows of services, knowhow and information. These increase the importance of intellectual property rights and legal frameworks. Financial liberalization - also essential for the easy movement of goods and capital — adds further complications to international policy.

The global negotiating agenda has dramatically widened, but even so has not kept pace with the expanding demands. In addition to taking on services, investment and intellectual property, the WTO was under pressure to expand still further - to issues such as labor, environment, competition — although it managed to jettison these at the Singapore ministerial in 1996. Nevertheless, in some countries negotiators are directed to address those issues as well, providing one additional reason for turning to bilateral and regional negotiations instead of the global track. 


\section{Institutional implications}

These trends - more diffuse interests, weaker domestic support, and more complex agendashave resulted in stalemate in global negotiations. Hopefully the Doha Round will be still concluded - if only to open opportunities for other modalities - but the agenda is now so complex, and the champions so few, that few observers expect such global rounds to drive the development of the trading system. New approaches will be needed to create a manageable architecture for progress.

One result of these trends is that trade negotiations have been pushed onto bilateral and plurilateral tracks. Before 2000 only 33 such agreements had been concluded by the Asian member countries in the ADB, but in the next nine years that number jumped to $216 .{ }^{11}$ Other world regions have experienced similar trends and nearly all regional trade in Europe and Latin America, and much of the trade within Asia is now covered by bilateral or regional agreements (Figure 7).

Figure 7. Share of regional trade covered by FTAs.

The sub-global track is attractive for several reasons: it allows forward movement despite the global stalemate, and it allows countries to liberalize while avoiding the most difficult political concessions. Sub-global agreements can address more issues and develop more flexible agreements than global negotiations. Many bilateral and regional negotiations address "WTO plus" issues in services, investment, competition, environment and other areas. Some also incorporate capacity building and aid as compensation for market access concessions by developing countries.

In the Asia Pacific, the regional trade network has been built largely on the ASEAN process. In addition to its core AFTA agreement, in 2007 ASEAN adopted an ambitious blueprint to build an ASEAN Economic Community. It has also concluded agreements with the "plus three" countries (China, Korea and Japan) and the other "plus six" counties (India, Australia and New Zealand). This hub-and-spoke network has been estimated to produce benefits of around 10 percent of the ASEAN income (Plummer 2009). In the meantime, India, Australia and New

\footnotetext{
${ }^{11}$ Asian Development Bank, ARIC http://aric.adb.org/5.php accessed September 25, 2009.
} 
Zealand have also negotiated agreements with Japan and Korea, and have negotiations underway with China. A China-Japan-Korea ("CJK") agreement is under discussion too, but faces much larger political and economic obstacles.

The theoretical debate about whether regional agreements are stepping stones or stumbling blocs toward an integrated global system is unsettled (Baldwin 1997, Bhagwati et al. 1999), but there is good evidence that Asia's free trade areas have been trade creating (Kreinin and Plummer 2000). FTAs may provide a route to broader liberalization by setting off a "domino effect" that makes it more advantageous for countries to join expanding blocs (Baldwin 1999), and by chipping away at interests that favor protection (Baldwin 1996, McCulloch and Petri 1997). Regional agreements can also incorporate assistance that makes countries more willing to undertake market-opening measures that require adjustment. And success on regional efforts might also shake up global negotiations enough to renew interest in a global framework. Even if not, large regional agreements could integrate a large part of the world economy, delivering most potential efficiency gains.

\section{Managing after the crisis}

We have argued that further global liberalization - and deepening interdependence driven by liberalization - will become less important in driving growth in the future than in the golden era. This also implies adjustments in the objectives and forms of international cooperation. Possible features of the transition are summarized in Table 1.

Table 1. Shifting Pattern of International Cooperation

\begin{tabular}{lll}
\hline $\begin{array}{l}\text { Elements of } \\
\text { cooperation }\end{array}$ & \multicolumn{1}{c}{ Golden era } & \multicolumn{1}{c}{ Next era } \\
\hline Objective & Global economic integration & $\begin{array}{l}\text { Interdependent growth; deeper } \\
\text { integration in smaller groups }\end{array}$ \\
Policy & $\begin{array}{l}\text { Liberal rules for cross-border } \\
\text { transactions }\end{array}$ & $\begin{array}{l}\text { Fair regulatory treatment; } \\
\text { sub-global integration }\end{array}$ \\
Tools & Legal agreements & $\begin{array}{l}\text { Institutions for consultation and } \\
\text { conflict resolution }\end{array}$ \\
\hline
\end{tabular}


The objective of global cooperation is likely to shift from seeking new agreements to managing existing ones. Deeper integration may remain an important objective, but it will be pursued by smaller groups of countries that can manage its complexity. These groups can tailor liberalization agendas to match economic requirements and steer clear of the political pitfalls associated with the global process. These parallel tracks pose new institutional demands-for flexible, ongoing commercial diplomacy at the global level, for more ambitious integration at the sub-global level, and for new approaches to integrating these two. We next explore the rationale and possible operation of this multi-track process.

\section{Layered institutions}

A layered institutional framework would permit global institutions to manage global interdependence while permitting deeper cooperation on sub-global tracks. The theoretical foundations for a layered approach rest on the theory of clubs (Kawai and Petri, 2010).

Theory suggests that international "clubs" are not structured to evolve over time- they tend to set high hurdles for changes in mission and governance. ${ }^{12}$ As a result, global institutions suffer from the "governance trilemma" illustrated in Figure 8. International institutions should be (a) democratic in providing voice to all members; (b) effective in delivering efficient public goods, and (c) universal in accepting all countries that take on the obligations of membership. But in practice global institutions do not appear to be able to meet all three of these goals. There are "universal and democratic" institutions (such as the United Nations and the WTO), but these have trouble implementing decisions. There are also "democratic and effective" institutions (such as the G7), but these are not universal and hence not considered illegitimate. And there are "universal and effective" institutions (like the IMF and the World Bank and GATT, before its

\footnotetext{
${ }^{12}$ Governments and firms are responsible to broad groups of shareholders or voters and adjust their services to maximize the value of their assets. By contrast, as long as a club exists, it produces services only for its controlling members, even if its assets could be more productively used elsewhere. In theory, inefficient clubs could disband and release assets, but they seldom do.
} 
transformation into the WTO), but these have been effectively governed by small subsets of members.

\section{Figure 8. The governance trilemma}

One solution to the trilemma is a layered architecture for making decisions. In such a structure, smaller "democratic and effective" institutions (say, regional trade groups) are the principal loci of actions, ideally subject to coordination by a "universal" global framework (say, G-20 leadership or rules such as GATT article XXIV). This is akin to functional federalism within larger countries, and to the principle of subsidiarity in Europe (Casella and Frey, 1992). This framework can generate a wider range of public goods than are possible under universal clubs.

Layered cooperation needs to be guided by a coordination mechanism to assure coherence. This is especially important, for example, in trade and standards, where inconsistent decentralized decisions would lower global welfare. UN peacekeeping operations provide an interesting model: various groups of countries funds and implement peacekeeping missions, but the Security Council has to approve all of them. This permits new public goods to be developed subject to system-wide oversight. An alternative is to produce lower-level public goods with similar, complementary regional institutions, such as regional development banks. Although these institutions don't have explicit coordination rules, their overlapping shareholders and frequent interactions provide a measure of consistency.

It remains to be seen whether an effective layered approach emerges from the current institutional crisis. Before the crisis institutions had begun to emerge below the global level, presumably to address the "effectiveness" deficit, including bilateral agreements and meetings such as the Strategic and Economic Dialogue between China and the United States, and multilateral macroeconomic cooperation through the ASEAN+ and Chiang Mai processes. The crisis of 2008-09 has created a new layer of decision-making above the global institutions, with the G-20 as a new "premier forum for international economic cooperation" (G-20 2009). These could be seen as addressing the "democracy" and "effectiveness" deficits by creating a small, but representative leadership for the global process. 
Whether the G-20 can break the issues that stalled cooperation in recent decades remains to be seen. The G-20 is itself large and diverse enough to make it difficult to address divisive issues, especially as the urgency of crisis subsides. Diffuse economic power and declining hegemony are also in evidence within the G-20. To get things done, the G-20 will need other, effective implementing bodies. Since the existing international institutions also face structural problems, they must be reformed into, or replaced by, a new layer of institutions (organized around common regional or economic interests) that provide effective governance.

\section{Institutional layering in practice}

A multi-layered system could be built from the top down. For example, the G-20 might become cohesive enough to direct and monitor international institutions in administering policy. In this case, the G-20 could ensure that the global institutions are strengthened and that national bureaucracies cooperate with them. This is a tall order: even if governance reforms make the international institutions more democratic, they may not make them more effective. NGOs and critics will still question their legitimacy, and they may still find themselves unable to influence important national policies. Inevitably, they will become targets for political criticism.

Alternatively, a multi-layered system could develop from bottom up cooperation among regional and functional institutions. In Asia alone, 14 "major economic cooperation groups" have been identified by the ADB (2008, pp. 256-259). For now, these groups are often little more than talk shops. To be effective, they would need more support from governments, including resources to back up policy decisions. For example, a new model for liquidity insurance based on the Chiang Mai Initiative Multilateralized (CMIM) would need to develop adequate analytical capability in the CMIM as well as clear rules for coordination with the IMF.

A bottom-up approach, however, may make it difficult to act jointly and quickly. It will be effective when relatively few countries are involved, when political sensitivities that constrain global cooperation are high, and when the participants have some agreement on the problems and solutions to be tackled. For example, negotiations to "rebalance" US and Chinese demand might make headway in a bilateral strategic dialogue rather than a politically sensitive forum 
such as the G-20 Mutual Assessment Process. (Of course, these approaches might complement each other.)

A coherent global system will ultimately require both top-down and bottom-up approaches, and connections between them. These may consist of limits on the content of sub-global agreements and coordination between global and sub-global decision-making bodies.

In a famous theoretical contribution, Kemp and Wan (1976) offered a strategy-essentially lowering external tariffs by an amount sufficient to offset trade diversion-for ensuring that external partners are not hurt by preferential trade agreements. Baldwin (2006) further explores the logic of regional trade agreements and concludes that they are likely to become the main tool for improving the global trading system. He proposes three initiatives that the WTO could take to make regional agreements into "building blocks" for world trade:

- providing clearer information [on] and a deeper understanding of the effects of the multilateralisation of regionalism;

- setting up a negotiating forum for the coordination/standardisation/harmonisation of rules of origin and cumulation; and

- convening a forum of 'spokes' that would explore that possibility of mutually advantageous cooperation on hub-spoke FTAs in different regions of the world.

In Kawai, et al. (2009), colleagues and I pursued a Kemp-Wan strategy to the trade liberalization dilemma. We proposed that the WTO become a participant in the negotiation and administration of regional FTAs by offering to contract its trade-related analytical and dispute-resolution services to regional groups that adopt acceptable agreements. This approach would enable the WTO to monitor that trade agreements are openly administered, and it would give the WTO voice in structuring and modifying FTAs. Our proposal involved:

- $\quad$ setting up an office in the WTO to support and integrate limited trade liberalization, e.g. agreements that cover limited sectors and countries;

- developing realistic standards for limited trade liberalization, which would both strengthen and relax Article XXIV to permit a broader range of agreements while ensuring that these avoid injuring non-members; and 
- creating frameworks to consolidate sectoral and regional agreements into global agreements. Ideally such mechanisms could connect sub-global and global layers of cooperation, providing greater consistency across rules and facilitating their eventual consolidation into global rules.

\section{Conclusions}

The golden era of economic growth and integration that has driven global progress in the last 60 years has hit turbulence. Its challenges derive in part from success; diminishing returns to liberalization; the diffusion of global economic power; and growing pluralism in the politics of countries and regions. These trends have immobilized new initiatives for global integration. The 2008-2009 crisis, for example, has been handled outside existing institutions, in ones created or modified for that purpose.

As a result, the growth of the world economy is less likely to be driven by further liberalization and integration than in the past. This does not necessarily mean slower growth; other drivers may take the place of advances in interdependence, and integration could still proceed in more limited regional settings. But the trends suggest that global cooperation will need to seek new approaches. The negotiation-intensive, agreement-oriented modalities of the past are not addressing contemporary challenges. Instead, institutions now need to sustain existing levels of integration and manage conflict. This is the mission that the G-20 now faces.

At same time, international cooperation is emerging in smaller frameworks, including bilateral and plurilateral agreements and institutions. The challenge will be to make these globally coherent. Effective and coherent sub-global initiatives could complement the global process and provide a way to implement its priorities. Much intellectual and institutional capital has been invested in structuring global institutions; more intellectual and practical analysis of sub-global approaches could now have a significant payoff. A consistent strategy will require top-level guidance (perhaps through global institutions such as the IMF and the WTO) coupled with bottom-level decision-making authority. The joint efforts by the IMF and the European Union 
on European rescues, as well as other examples noted in this paper, could provide models for such cooperation.

This is an extraordinary time of change for global institutions. It will take time for the right new institutions and processes to develop. Hopefully shocks to the global economy will be mild and infrequent enough in the interim - in contrast, say, to the shocks between the World Wars - to allow an effective new framework to emerge. 


\section{REFERENCES}

Asian Development Bank. 2008. Emerging Asian Regionalism: A Partnership for Shared Prosperity. Manila: Asian Development Bank.

Baldwin, Richard E. 1997. "The causes of regionalism," The World Economy, 20:7, pp 865-888.

-----. 1999. “A domino theory of regionalism,” in J. Bhagwati, P. Krishna and A. Panagariya (1999), Trading blocs: Alternative approaches to analyzing preferential trade agreements, Cambridge: MIT Press. 479-502.

-----. 2006. "Multilateralizing Regionalism: Spaghetti Bowls as Building Blocs on the Path to Global Free Trade.” NBER Working Paper No. 12545. Cambridge: National Bureau of Economic Research.

Barton, John H., Judith L. Goldstein, Timothy E. Josling, and Richard H. Steinberg. 2006. The Evolution of the Trade Regime: Politics, Law and Economics of the GATT and the WTO. Princeton: Princeton University Press.

Bhagwati, Jagdish, P. Krishna and A. Panagariya. 1999. Trading blocs: Alternative approaches to analyzing preferential trade agreements, Cambridge: MIT Press.

Bordo, Michael D. 2002. "Globalization in Historical Perspective,” Business Economics, pp. 2029. January.

Capannelli, Giovanni, Jong-Wha Lee and Peter A. Petri. 2010. "Economic Interdependence in Asia: Developing Indicators for Regional Integration and Cooperation," Singapore Economic Review, V 55. No. 1. pp. 125-161.

Casella, Alessandra and Bruno Frey, 1992. "Federalism and clubs: towards an economic theory of overlapping jurisdictions," European Economic Review, 36, 639-646.

Clemens, Michael A. and Jeffrey G. Williamson, 2001. “A Tariff-Growth Paradox: Protection's Impact the World Around 1875-1997.” NBER Working Paper No. 8459, Cambridge: National Bureau of Economic Research.

Coe, D. T., A. Subramanian, N. T. Tamirisa, and R. Bhavnani. 2002. "The Missing Globalization Puzzle," IMF Working Paper, WP/02/171. Washington: International Monetary Fund.

Cohn, Theodore H. 2002. Governing Global Trade: International Institutions in Conflict and Convergence. London: Ashgate.

Dobson, Wendy, Gary Clyde Hufbauer and Hyun Koo Cho. 2001. World Capital Markets: Challenge to the G-10. Washington: Peterson Institute for International Economics. 
Easterly, William. 2005. National Policies and Economic Growth: A Reappraisal. In Philippe Aghion and Steven Durlauf eds. Handbook of Economic Growth, V.1, Amsterdam: Elsevier, 1015-59.

Estevadeordal, Antoni and Alan M. Taylor, 2008. "Is the Washington Consensus Dead? Growth, Openness, and the Great Liberalization, 1970s-2000s," NBER Working Paper 14264, Cambridge: National Bureau of Economic Research.

Feenstra, Robert C. 1998. "Integration of Trade and Disintegration of Production in the Global Economy," Journal of Economic Perspectives, 12:4 p. 31-50. Fall.

Findlay, Ronald and Kevin H. O.Rourke, 2001. "Commodity market integration, 1500-2000." NBER Working Paper 8579. Cambridge: NBER.

Fukao, Mitsuhiro. "Capital account liberalisation: the Japanese experience and implications for China." www.bis.org/publ/bppdf/bispap15h.pdf

G-20. 2009. "Leaders Statement: The Pittsburgh Summit." Online at http://www.pittsburghsummit.gov/mediacenter/129639.htm.

Gowa, Joanne. 2009. "Institutions and Outcomes: The GATT/WTO and Postwar Trade." Department of Politics, Princeton University. Processed.

Irwin, Douglas A. 1996a. Against the tide: an intellectual history of free trade. Princeton: Princeton University Press. . 1996b. "The United States in a New Global Economy? A Century's Perspective." The American Economic Review, 86:2, pp. 41-46. May.

Kawai, Masahiro and Peter A. Petri. 2010. "Asia's Role in the Global Economic Architecture." Working Paper No. 235. Tokyo: Asian Development Bank Institute.

Kawai, Masahiro, Peter A. Petri and Elif Sisli-Ciamarra. 2009. “Asia in Global Governance: A Case for Decentralized Institutions." Processed.

Kemp, Murray C. and H. Wan. 1976. "An Elementary Proposition Concerning the Formation of Customs Unions,” Journal of International Economics, 6:1, pp. 95-97.

Keohane, Robert O. 1984. After Hegemony: Cooperation and Discord in the World Political Economy. Princeton: Princeton University Press.

Kreinin, Mordechai and Michael Plummer. 2000. Economic Integration and Asia: the Dynamics of Regionalism in Europe, North America and the Asia-Pacific. Cheltenham: Edward Elgar.

Krueger, Anne O. 1974. "The Political Economy of a Rent-Seeking Society." American Economic Review, Vol. 64:3, pp. 291-303. June. 
Leibenstein, Harvey. 1957. Economic Backwardness and Economic Growth. New York: Wiley.

Maddison, Angus. 2001. The World Economy: A Millennial Perspective. Development Centre Studies. Paris: OECD.

McCulloch, Rachel and Peter A. Petri. 1997. "Alternative Paths Toward Open Global Markets," in Keith E. Maskus, Peter M. Hooper, Edward E. Leamer and J. David Richardson, eds. Quiet Pioneering: Robert M. Stern and His International Economic Legacy. pp. 149-169. Ann Arbor: University of Michigan Press.

Patrick, Hugh. 1996. 'From PAFTAD to APEC: Homage to Professor Kiyoshi Kojima', Surugadai Economic Studies, 5:2, March.

Petri, Peter A. 2010. "Asia and the World Economy in 2030: Growth, Integration and Governance," in Ashley J. Tellis, Andrew Marble and Travis Tanner, eds. Asia's Rising Power and America's Continued Purpose, Seattle: National Bureau of Asian Research.

Plummer, Michael G. and Chia Siow Yue. 2009. Realizing the ASEAN Economic Community: A Comprehensive Assessment. Ed. Singapore: ISEAS Press.

Rodrik, Dani. 2003. “Growth Strategies.” Harvard University Kennedy School of Government. Processed.

Rose, Andrew. 2007. "Do We Really Know that the WTO Increases Trade? Comment." The American Economic Review. 97:5. 2019-25.

Rosenstein-Rodan, Paul. 1943. "Problems of Industrialization of Eastern and Southeastern Europe.” Economic Journal 53(210-211) June-September. 202-211.

Sachs, Jeffrey D. and Warner, Andrew M. 1995. Economic reform and the process of global integration. Brookings Papers on Economic Activity. 1-118.

Schott, Jeffrey J. ed. 2000. The WTO After Seattle. Washington: Institute for International Economics.

Terada, Takashi. 1999. "The Japanese Origins of PAFTAD: The Beginning of an Asian Pacific Economic Community" Pacific Economic Papers No. 292. Canberra: Australian National University.

Tomz, Michael, Judith Goldstein, and Douglas Rivers. 2007a. "Institutions in International Relations: Understanding the Effects of the GATT and WTO on World Trade." International Organization 61, 1:37-68.

. 2007b. "Do We Really Know that the WTO Increases Trade? Comment." The American Economic Review. 97:5. 2005-18. 
Williamson, John. 1989. "What Washington Means by Policy Reform," in Williamson, John (ed.). Latin American Readjustment: How Much has Happened. Washington: Institute for International Economics.

World Bank. 1991. World Development Report: The Challenge of Development. Washington: World Bank.

. 1993. The East Asian Miracle: economic growth and public policy. Oxford: Oxford University Press. 


\section{FIGURES}

Figure 1. The golden era in perspective:

Average annual growth rates of GDP

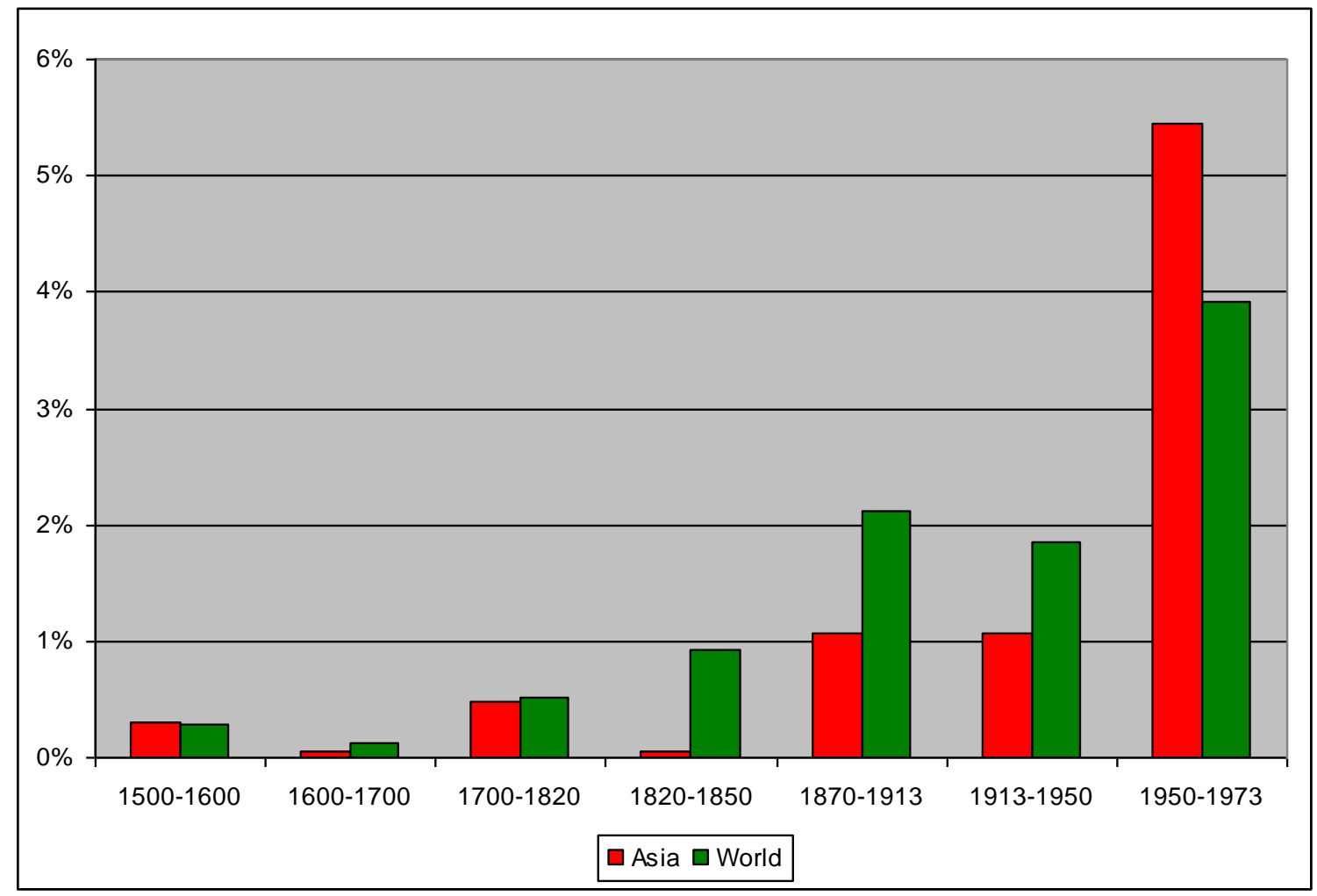

Source: Maddison (2001), p. 261. 
Figure 2. Declining world protection:

Unweighted average tariffs for 35 countries

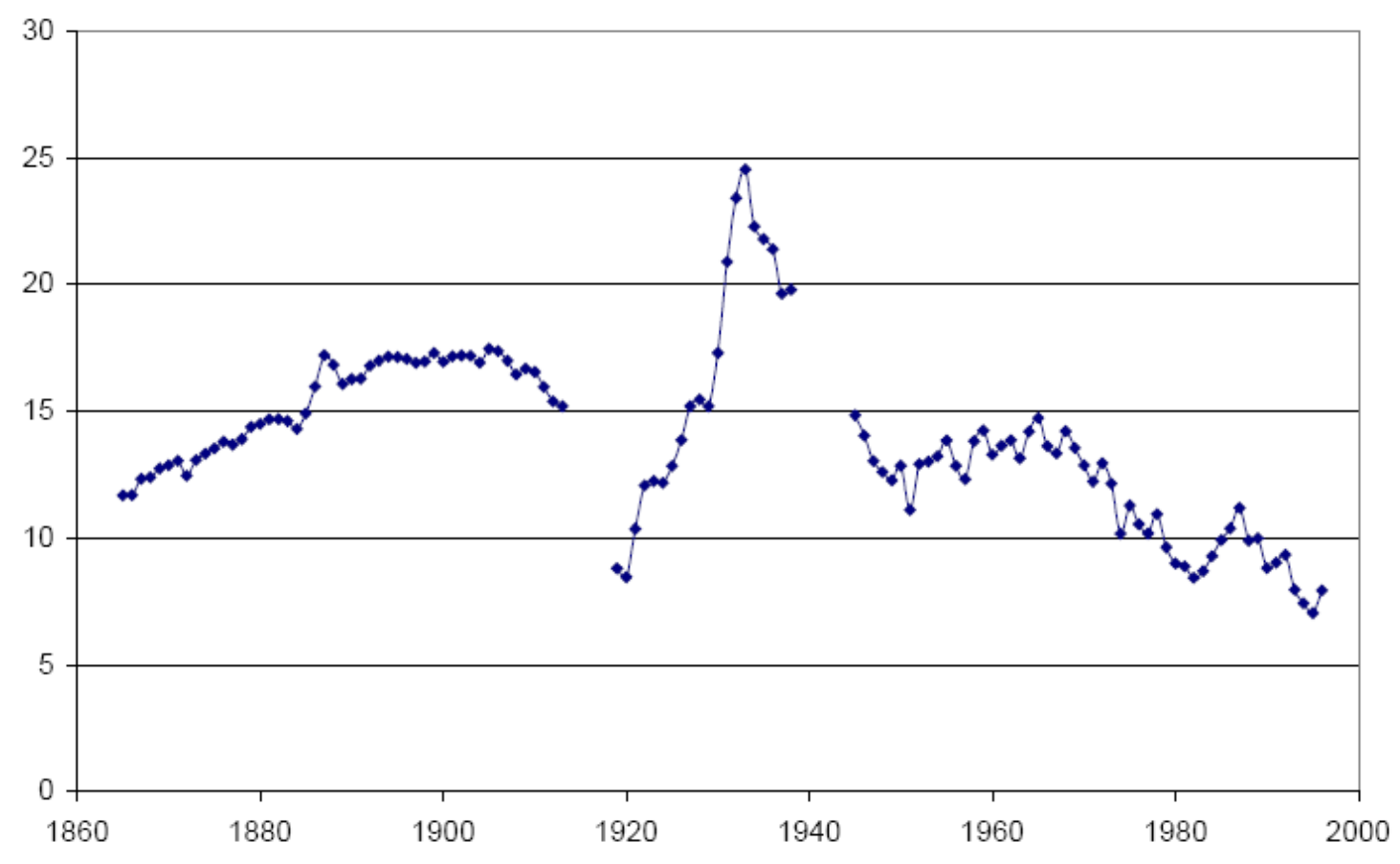

Source: Clemens and Williamson (2001), Figure 1. 
Figure 3. Lengthening negotiations:

Months vs. number of participants in successive GATT rounds

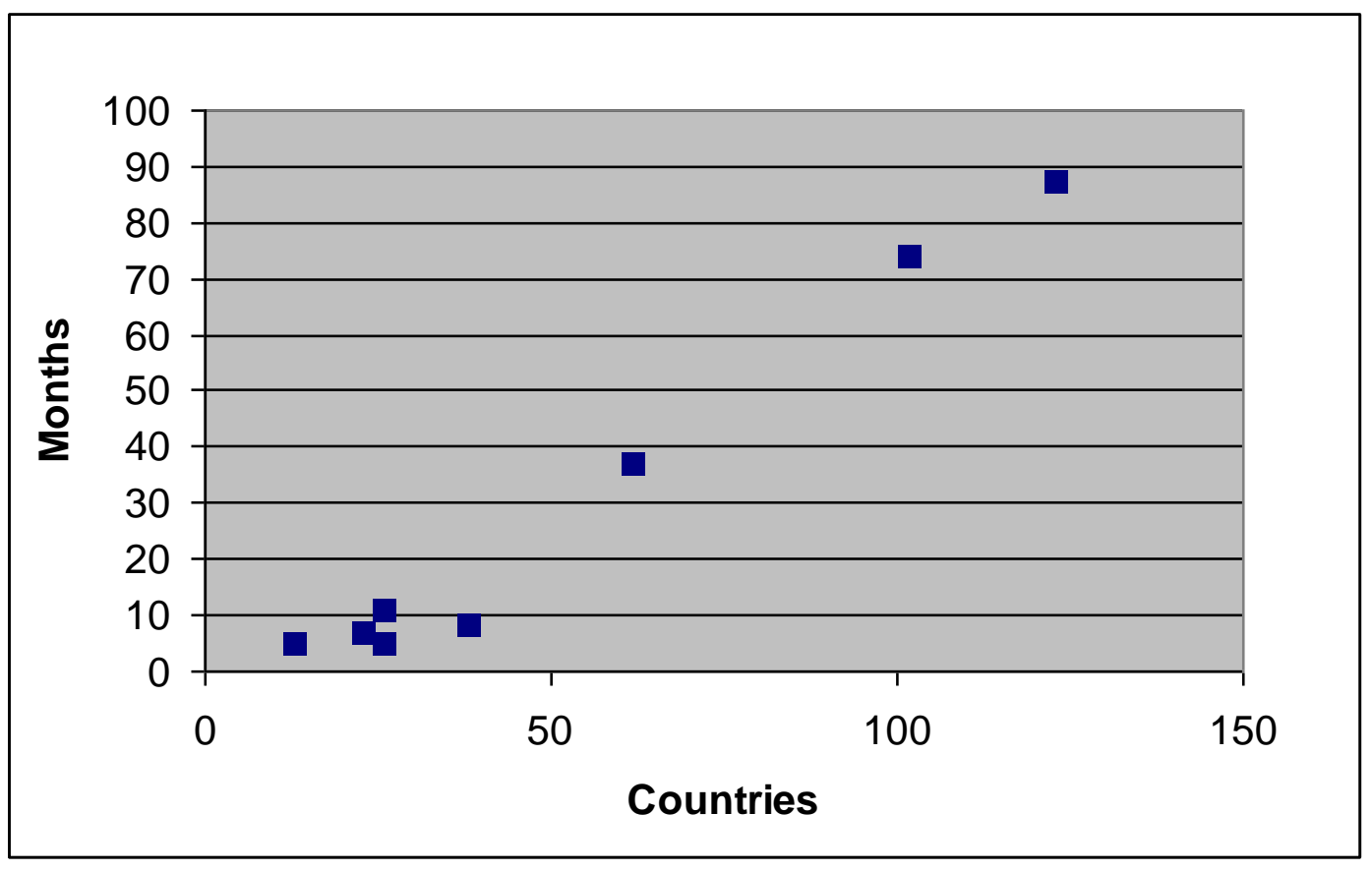

Source: WTO, http://www.wto.org/english/thewto_e/whatis_e/tif_e/fact4_e.htm 
Figure 4. Rebounding trade:

Share of average of imports and exports in GDP

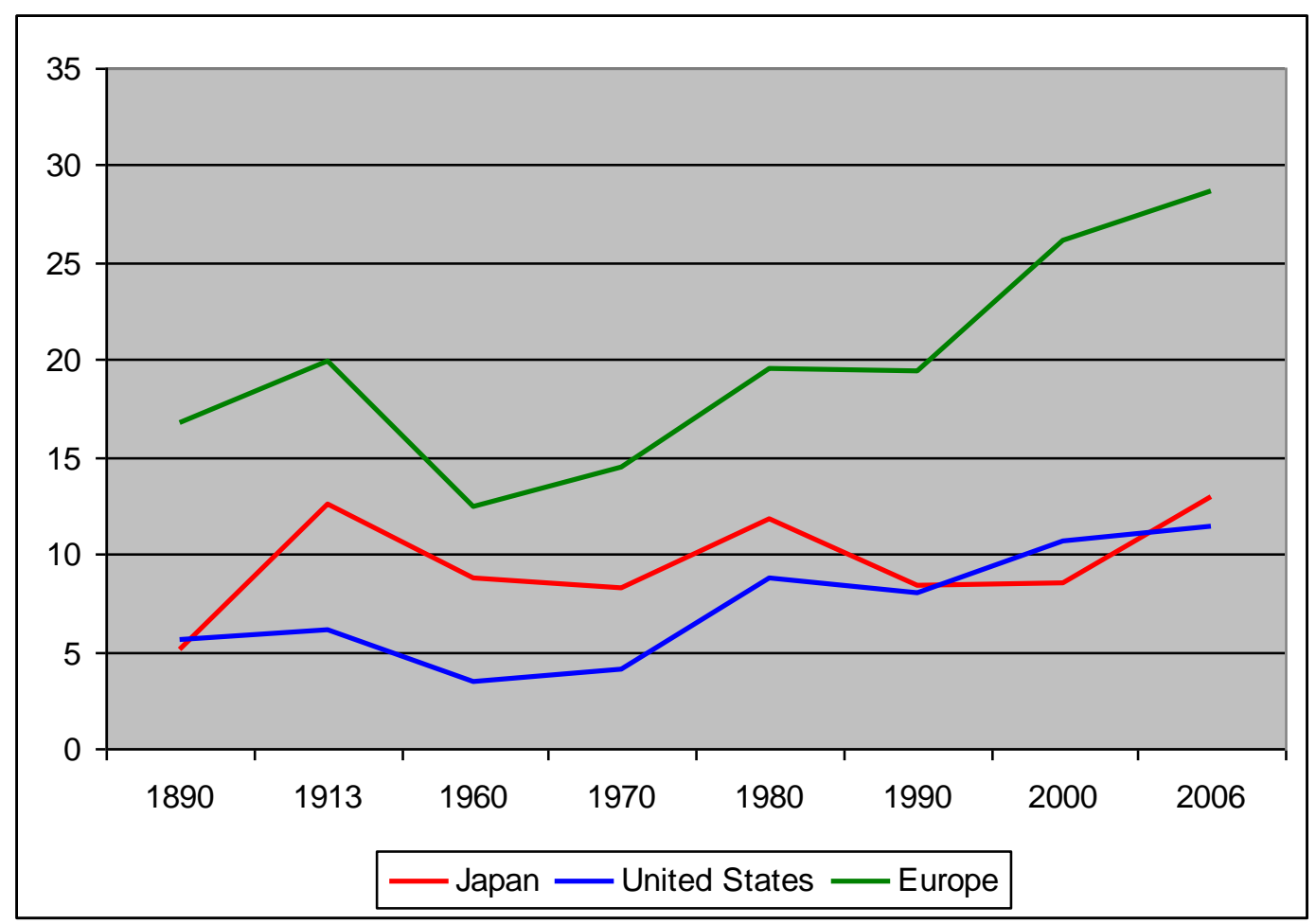

Source: Feenstra (1996), p. 33. Feenstra's data extended using World Bank, World Development Indicators, extracted on September 25, 2009.

Note: Europe represents a simple average of France, Germany, Italy and the UK. In the data extension it represents the Euro area. 


\section{Figure 5. Exploding capital flows}

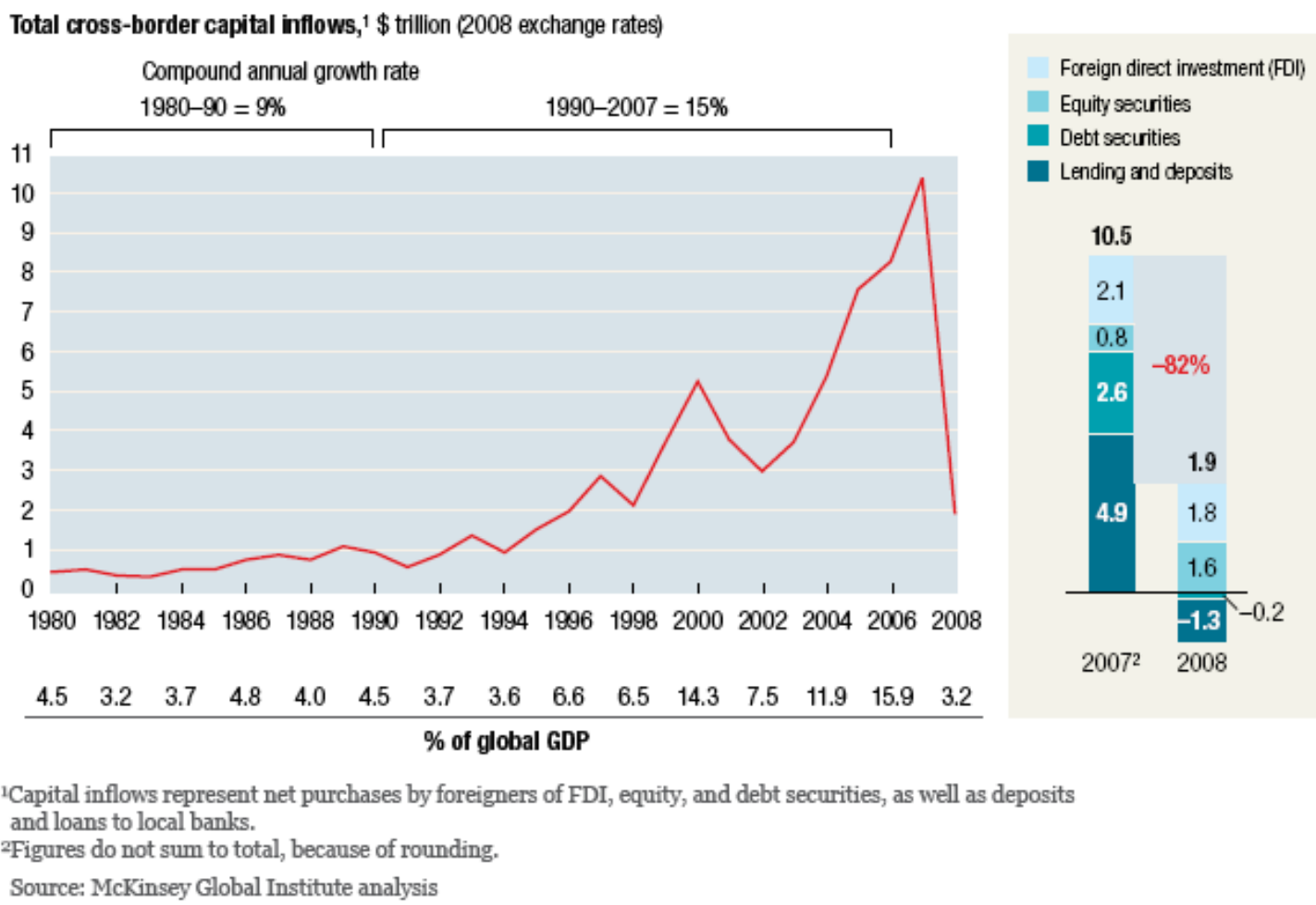


Figure 6. Changing weights:

Shares US, Europe and East Asia in world GDP

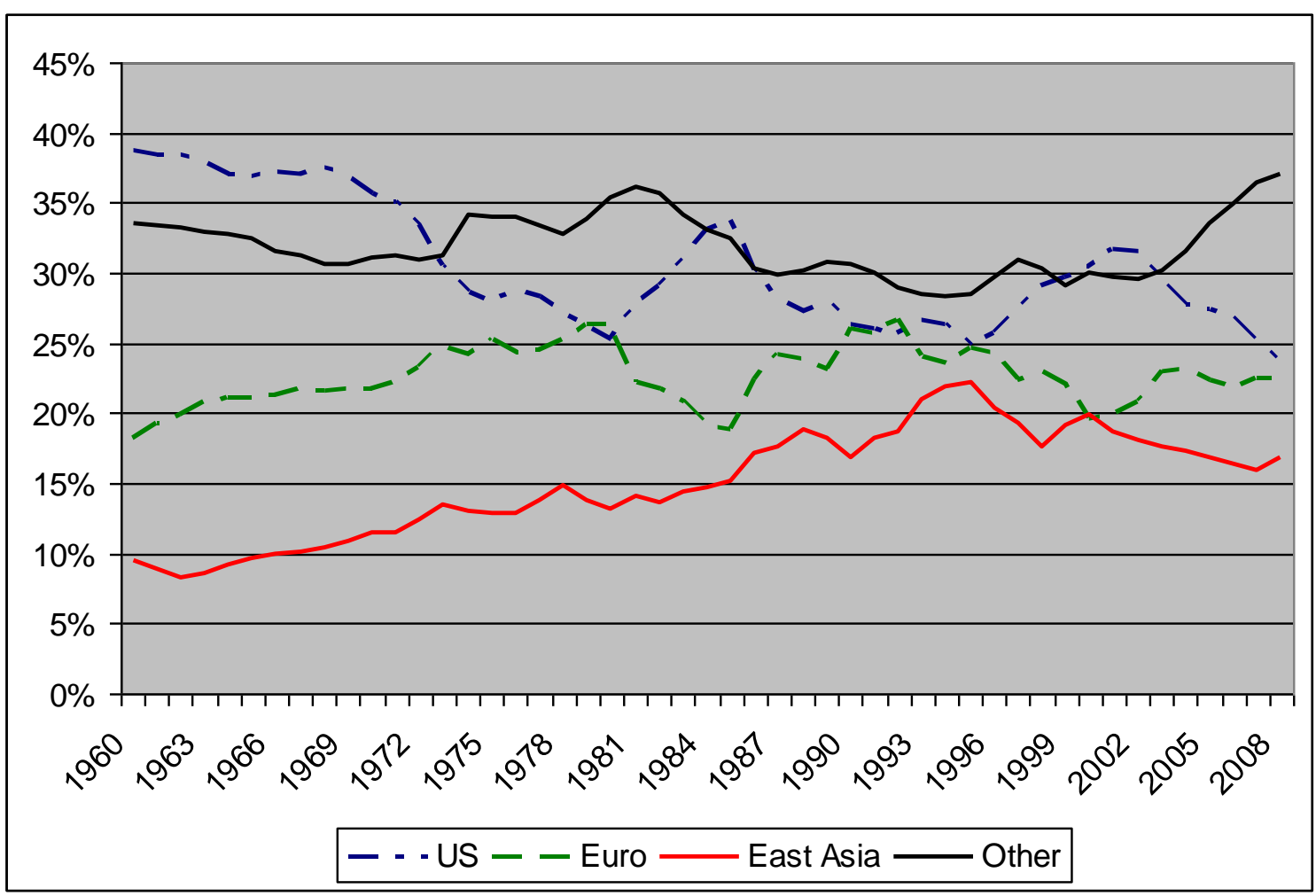

Source: World Bank, World Development Indicators, extracted 25 September 2009. 
Figure 7. Rising FTA coverage:

$\%$ of possible country pairs covered by an agreement

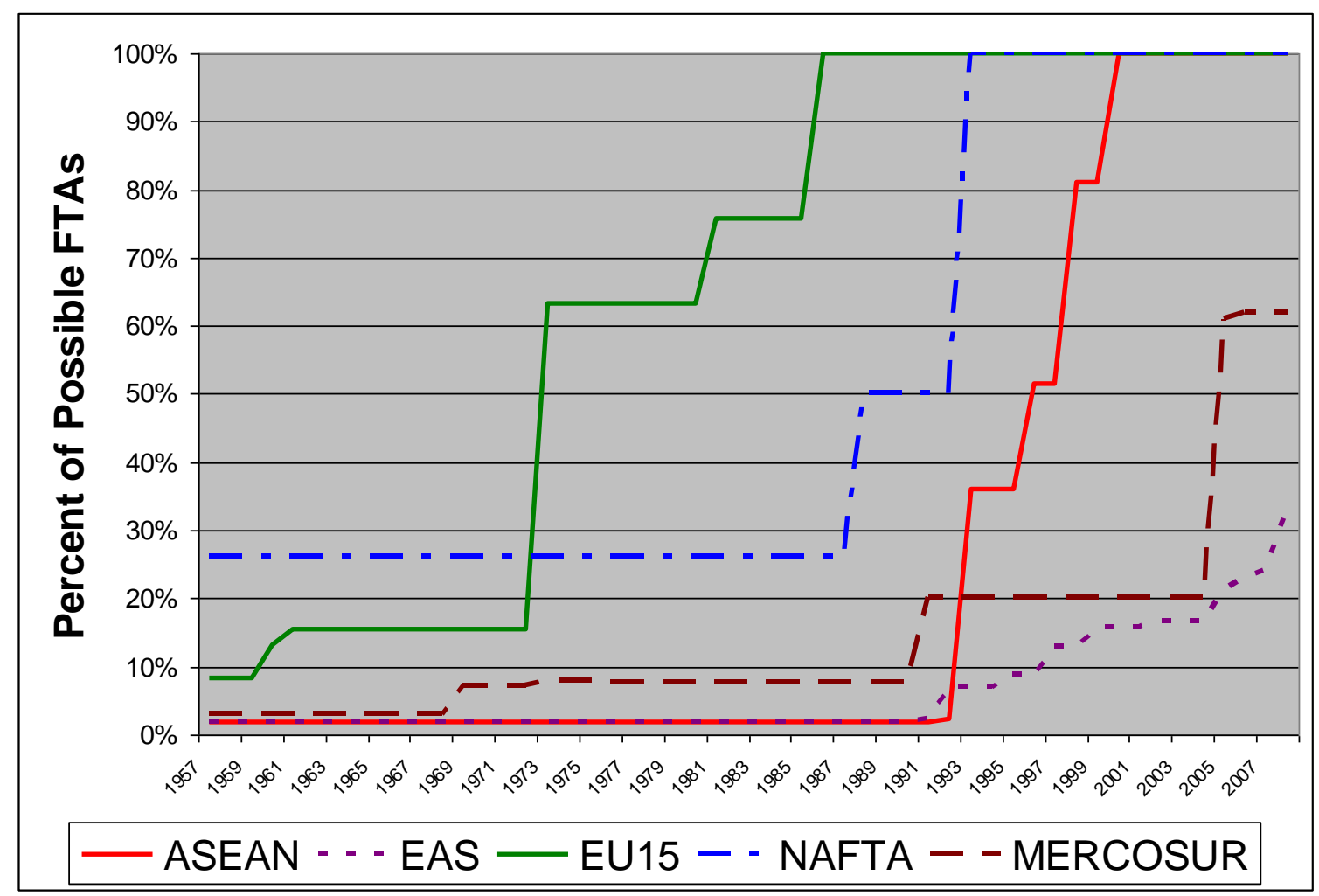

Source: Capannelli et al. (forthcoming). 
Figure 8 . The governance trilemma

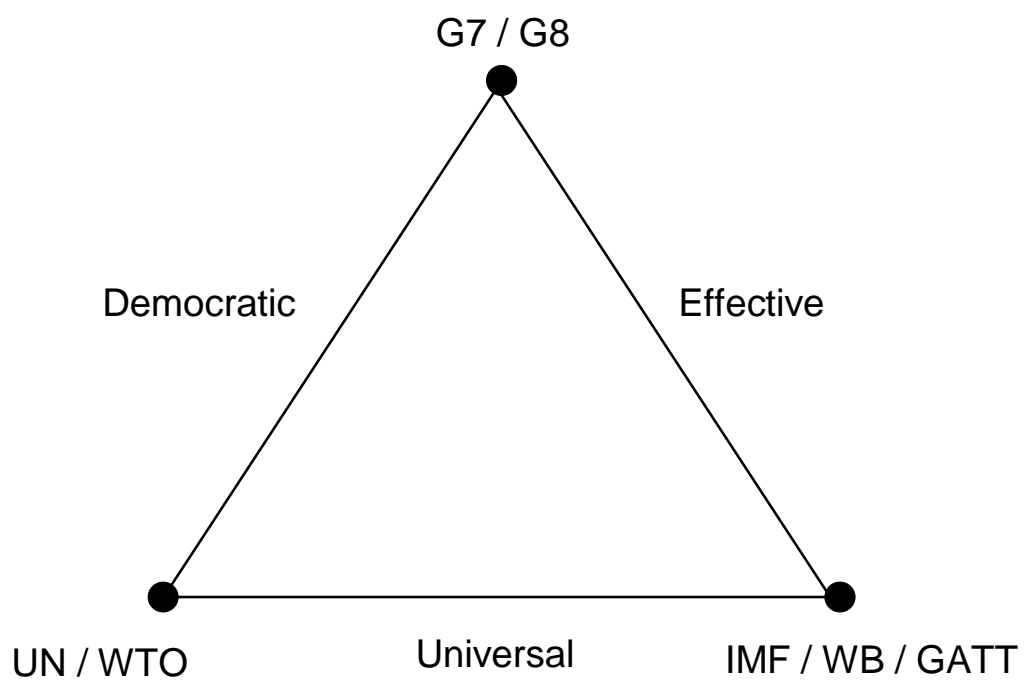

Source: Kawai et al. (2009). 